\title{
VERSITA
}

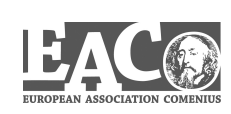

\section{Characteristics of the Large Corporation-Based, Bureaucratic MOdel AMONG OECD COUNTRIES - AN FOI MODEL ANALYSIS}

\author{
Zoltán Bartha ${ }^{1}$, Andrea S. Gubik ${ }^{2}$
}

\begin{abstract}
Deciding on the development path of the economy has been a delicate question in economic policy, not least because of the trade-off effects which immediately worsen certain economic indicators as steps are taken to improve others. The aim of the paper is to present a framework that helps decide on such policy dilemmas. This framework is based on an analysis conducted among OECD countries with the FOI model (focusing on future, outside and inside potentials). Several development models can be deduced by this method, out of which only the large corporation-based, bureaucratic model is discussed in detail. The large corporation-based, bureaucratic model implies a development strategy focused on the creation of domestic safe havens. Based on country studies, it is concluded that well-performing safe havens require the active participation of the state. We find that, in countries adhering to this model, business competitiveness is sustained through intensive public support, and an active role taken by the government in education, research and development, in detecting and exploiting special market niches, and in encouraging sectorial cooperation.
\end{abstract}

\section{Keywords}

Development Factors, Development Paths, FOI Model, OECD Countries

\section{Introduction}

As growth rates have slowed across the developed world since 2008, the topic of economic development has become more relevant than ever. Governments across the globe seem to be struggling to find the right economic policy instruments that will make their economies

\footnotetext{
${ }^{1}$ Faculty of Economics, University of Miskolc, 3515 Miskolc-Egyetemváros, Hungary. E-mail: zolib@hu.inter.net.

${ }^{2}$ Faculty of Economics, University of Miskolc, 3515 Miskolc-Egyetemváros, Hungary. E-mail: getgubik@unimiskolc.hu.
} 
more dynamic. The aim of this paper is to contribute to the literature of economic development by identifying crucial development factors, and describing a special development path that we call the large corporation-based, bureaucratic model.

The method used to deduct the large corporation-based, bureaucratic model is called the FOI model. It was developed by the authors within the framework of a research project funded by the Hungarian Scientific Research Fund between 2009 and 2013. The FOI model is based on the assumption that there are several ways to achieve economic development. Its structure was formulated in such a way as to make it possible to capture the significant differences in the development paths taken by different nations. Using the sample of the OECD countries, we detected three viable development paths, one of them being the large corporation-based, bureaucratic model.

The large corporation-based, bureaucratic model is characterised by a strong and competitive business environment, but the countries choosing this path are also characterised by a strong state presence. We used country studies to be able to show how these two elements can be combined successfully, and our findings may therefore be used to shape economic policy decisions.

\section{Growth and development in economics}

Growth and development are mentioned almost as synonyms in this paper, although the literature usually addresses them separately. The simplest approach is to say that growth is the narrower, and development is the more complex class, as growth is usually defined as an increase in certain quantitative variables, while development describes a process of moving from a lower level of quality to a higher one (Szentes, 2011). As the measurement of the phenomena economics usually deals with is in any case problematic, the most popular, formalised growth models (e.g. Domar, 1947; Harrod, 1948; Solow, 1956; Romer, 1986 and Lucas, 1988) concentrate on national income or on its per capita version. These models therefore map the problem of growth/development through the quantitative change of a single indicator, so they offer tools to analyse the problem of growth, the narrower category.

However, GDP - being an aggregate indicator - veils more profound processes that are crucial for development, such as the structure of the economic system, changes in employment, income distribution or the institutional framework, etc. For this reason, we will from now on use the more complex approach to development whenever we touch upon issues of growth and/or development paths, factors of growth and/or development, meaning that we interpret development as a combination of two things: growth in the indicators of national income, and the modernising of the socioeconomic structures.

\section{Theories of development}

Different schools of economics have different views on the rules of the economy, and neither do they agree on the basic assumptions; hence, a wide variety of theories have been developed over the centuries. While most schools implicitly assume that the models used are universal, List (1841) was convinced that the classical theories may only apply to the most developed economies; the followers of new institutionalism (see Williamson, 
2000, for example) point out that the institutional structure of different countries can be very different. A similar confrontation can be observed regarding development paths. It is widely accepted that development is unilinear, meaning that all countries have to go through the same development stages (with timing being the only difference among them). Veblen (1919), on the other hand, argued against the teleological approach of economics, and suggested an evolutionary one instead.

It worth mentioning that mainstream theories do not consider the effects of national interests and bargaining power in their models; heterodox schools, on the other hand, cannot accept the independent development of countries (although there is no agreement among them considering the exact nature of the interdependencies). It may seem natural to choose the countries and national economies as the unit of analysis; Wallerstein (1974), however, when describing the economic history of medieval Europe, concludes that modernisation cannot be understood within the framework of the national economy. He instead chooses the world system as the unit of analysis.

Some scholars have developed models with few explanatory factors; others have gone for more variables. The well-known growth theories pick one or two variables; Porter's diamond model (1990) combines four quite complex factors; the empirical study of Barro (1998) of 100 countries over 30 years finds seven factors that are strongly connected to the growth rate of real GDP.

The factors of development identified in economics literature can be categorised along many principles, but the location of factors is probably the most important dividing line. One camp of economists traces back differences in economic development to reasons that can be found inside the country. They point to factors whose presence (e.g. physical or human capital) or lack (e.g. government failures) enables high growth rates. Another group of economists finds the causes of underdevelopment in outside factors. Usually these theories take the differences in the development level as given in the world economy, and they assume that these differences lead to asymmetric dependencies. The asymmetric dependencies, on the other hand, make it very difficult for underdeveloped countries to catch up with the rich world. The inside-outside distinction among the factors of development plays a crucial role in the model developed during our research.

\section{The inside factors of development}

Adam Smith (1776) saw the division of labour as the main source of wealth. Those countries that are able to extend the division of labour among their firms and citizens can become wealthier, as they are able to produce greater quantities from the same labour input. The main finding of the Harrod-Domar model $(1947,1948)$ is that investments are the key to economic growth. Investments, however, are mainly dependent on the savings rate. Around a decade later, Solow (1956) pointed out that investments and savings cannot contribute to growth in the long run. In his view, long-term economic growth is driven by technical change.

Keynes (1936) suggested that crises are generated by limits in demand, and the latter may be strengthened by large income differences. The speculative demand for money of those who are well off can be especially high, which prevents a substantial part of the income 
from turning into effective market demand. Inequalities in income distribution can thus be a setback for balanced growth.

Schumpeter (1934) stressed that cyclical fluctuations should be regarded as a natural part of the economy, as entrepreneurs may only draw profits if they break the status quo of equilibrium. The way to break the status quo is through innovation, which therefore becomes the primary driver of cyclical development. McClelland (1957) also emphasised the importance of the entrepreneurial class. In his view, entrepreneurs are the pioneers of development, and their biggest motivator is not profit, but the achievement of some special goals (N-achievement).

When the big colonial empires collapsed, several academics explained the situation of the underdeveloped former colonies with a value system and social structure that was different from the Western one. In underdeveloped countries the rural characteristics of society are dominant, meaning that labour is inefficient, immobile, the social structure is rigid, and the general attitude rejects individualism and risk taking (Meier, 1964). When local values confront Western values, society is split into two groups, and a dual social structure is formed (Boeke, 1953), a state which is completed with a dual economic structure (where the traditional and modern sectors are insulated from each other).

The role of human capital in growth and development is highlighted in various forms in the literature. Szentes (2011) quotes from A. Marshall: from a national perspective, the capital invested in workers' children is just as productive as capital invested in horses or machinery. Newer theories unquestionably suggest that capital invested in children is far more productive than that invested in horses and machinery. Endogenous growth theories see increasing returns as a prime source of long-term growth, and they directly or indirectly explain increasing returns with human capital. Lucas (1988) treats human capital as reproducible, an element of capital that the society is able to broaden at a constant rate. The expansion of human capital, on the other hand, leads to a constant increase in the productivity of physical capital. Romer (1986) can also be connected to human capital. In his model, investments made in research and development produce positive externalities that enable a constant increase in the productivity of physical capital.

Veblen (1919) points out that human behaviour is deeply affected by institutionalised rules of society. His views were taken over by new institutional economists (e.g. North, 1993; Williamson, 1998). According to them, institutions affect the incentive system of an economy, while the incentive system, on the other hand, influences the behaviour, size and competition of firms, the level of investments and technological development, and so, ultimately the level of development of an economy. Underdevelopment is thus explained by institutional frameworks consisting of bad incentives, according to the new institutional school.

Partially connected to the institutional approach is the theory of government failures, which was mainly brought to the attention of development experts by Tullock (1993). It was back in the 1960s that Tullock (1967) suggested that the super profits that monopolistic structures offer can be an incentive for firms to lobby for government regulations granting monopolistic positions and monopoly profits. According to calculations made by Krueger (1974), the rent-seeking behaviour of firms in the field of import licences caused a 7.3\% 
GDP loss in India, and a 15\% GDP loss In Turkey in 1964. The more corrupt a country is, the weaker the state is, the heavier the costs of rent seeking are, and so rent seeking can be one of the major obstacles of economic development.

Porter's (1990) national competitiveness theory adds some highly complex factors to the literature of economic development. A somewhat similar idea is suggested by Freeman (1987), who developed the theory of national innovation systems. These systems are centred on cooperation among businesses, the education system and the research infrastructure.

\section{The outside factors of development}

The theory of comparative advantage developed by Ricardo (1817) was one of the cornerstones of the laissez-faire approach of international relations. According to Ricardo, the highest welfare level can only be ensured if trade is conducted along the lines of comparative advantages and there is a free flow of goods. This free trade principle was questioned by many. List (1841) argued against laissez-faire. He defended protectionism, and suggested protective tariffs for newly-established industries (the infant industry argument). His suggestions echoed those of Alexander Hamilton (1791) made in the newly-formed USA. After the Second World War, the focus of development economics shifted towards the power relations of different countries. Prebisch (1964) and Myrdal (1957) point out that underdeveloped states are dependent on richer countries, and so the current system of international division of labour is not based on comparative advantages. The internal economic structures of most developing countries are directly influenced by the developed ones through the colonial system (Myrdal: forced bilateralism). Balogh (1963) argues that, as a result of power inequalities among parties, the economic structure of the developing countries has to be adjusted time after time to take into account the changes generated by technical progress made in the developed economies, and the adjustment process prevents them from achieving long-term growth. Dependency relations lead to one-track specialisation (Singer 1964). The majority of exports of the developing countries are primary products and commodities, which leads to a decrease in the terms of trade over the long run. Bhagwati, in his 1958 paper titled "Immiserizing growth", showed that the decrease in terms of trade can result in a decrease in the national income even if there is dynamic growth in the production of the export sector. One lesson learned from the literature of interdependencies is that a diversified export structure can be an important development factor.

Emmanuel (1972) has gone so far as to claim that trade between developing and developed countries is an unequal exchange, which is a manifestation of the imperialism of trade. Unequal exchange was triggered by wage differences, and is sustained by the immobility of labour. Wallerstein (1974) also accepted the concept of unequal exchange, although he argued that it is a result of the different bargaining power of nations. The core-periphery relations and the geographical position basically predestine the fate of nations, according to Wallerstein.

As the role played by transnational companies in the international flow of goods and capital became more and more dominant, a great deal of attention was directed towards them. Furtado (1970) suggested that the most important development factor is no longer 
interdependencies among countries, but the investment strategies of transnational companies. Transnational companies can bring capital to a country, creating jobs, but the newly-formed subsidiaries may be isolated from the local economy (Singer 1964). The ability of a country to attract foreign capital, especially if the capital is invested in fields that can fit in well with the current economic structure of the economy, is another important development factor.

The demonstration effects of modern consumer societies are also worth mentioning. Generally, the consumers of the developing countries try to follow the consumption patterns of the developed nations. This usually has a cut-down effect on local growth, as the goods most fitting to current consumption trends are generally produced overseas, so following the trends increases imports, and can contribute to the trade balance deficit.

Table 1: Inside and outside development factors

\begin{tabular}{|c|c|}
\hline Inside factors & Outside factors \\
\hline Division of labour (Smith) & $\begin{array}{l}\text { Free trade - international division of labour } \\
\text { (Ricardo) }\end{array}$ \\
\hline $\begin{array}{l}\text { Savings rate (Harrod-Domar) } \\
\text { Abundance-scarcity of capital }\end{array}$ & $\begin{array}{c}\text { Protectionism } \\
\text { Defence of infant industries (List) }\end{array}$ \\
\hline $\begin{array}{c}\text { Equal-unequal income distribution } \\
\text { (Keynes) }\end{array}$ & $\begin{array}{l}\text { Equal or unequal trade partners (Balogh) } \\
\text { Pressure to fit to modern patterns (Balogh) }\end{array}$ \\
\hline Drive to innovate (Schumpeter) & $\begin{array}{c}\text { Unilateral dependency - diversification } \\
\text { (Myrdal) }\end{array}$ \\
\hline Entrepreneurial behaviour (McClelland) & One-sided specialisation (Singer) \\
\hline $\begin{array}{c}\text { Rigid-flexible social structure (Meier) } \\
\text { Imported or organically developed social } \\
\text { structures (Boeke) }\end{array}$ & $\begin{array}{c}\text { Immiserising growth - terms of trade } \\
\text { (Bhagwati) } \\
\text { Forced bilateralism (Myrdal) }\end{array}$ \\
\hline $\begin{array}{l}\text { Dual-homogeneous economic structures } \\
\text { (Meier) }\end{array}$ & $\begin{array}{l}\text { International wage division- mobility of } \\
\text { labour (Emmanuel) }\end{array}$ \\
\hline $\begin{array}{l}\text { Investment into human capital (Marshall) } \\
\text { Human capital as a renewable resource } \\
\text { (Lucas) } \\
\text { Positive externalities of R\&D (Romer) }\end{array}$ & $\begin{array}{c}\text { Geographical position - core and periphery } \\
\text { (Wallerstein) }\end{array}$ \\
\hline $\begin{array}{c}\text { Institutional incentives (North) } \\
\text { Path-dependent development }\end{array}$ & $\begin{array}{l}\text { Investment strategies of multinational } \\
\text { companies (Furtado) }\end{array}$ \\
\hline $\begin{array}{c}\text { Government failure (Tullock) } \\
\text { Rent-seeking (Krueger) } \\
\text { National diamond (Porter) } \\
\text { Innovation systems (Freeman) } \\
\text { Rule of law, democracy (Barro) }\end{array}$ & Demonstration effect \\
\hline
\end{tabular}

\section{The role of institutions in development}

According to the followers of the institutional school, institutions affect human behaviour; in other words they influence the decisions of economic agents. Veblen was the first to point that out (1919), and also added that it is an oversimplification to assume that market decisions can be analysed independently from any other outside factors, like family, culture, 
community, politics, etc. His views were neglected by mainstream economics, but the topic was brought to the forefront again by two new research agendas.

On the one hand, it was proved by a series of psychological experiments that we are not capable of making such rational decisions as is assumed by economics. The notion of homo economicus was debunked by the theory of bounded rationality (Simon, 1957). Agents with bounded rationality behave opportunistically. On the other hand, Coase's pioneering article (Coase, 1937) shed light on the fact that the transactions conducted among agents are not frictionless, and, depending on the rate of frictions, very different market solutions may prove to be the most efficient ones. If we take a closer look at market transactions, it becomes clear that there are numerous social phenomena that are disregarded by mainstream economics, yet they influence the opportunistic behaviour of market agents and the rate of frictions during transactions. These social phenomena are collectively called institutions.

Hodgson defines institutions (2006) as systems of established and prevalent social rules that structure social interactions. According to the definition above, language, money, etiquette, the measurement system, and firms can all be regarded as institutions. Institutions make it easier to calculate and forecast the behaviour of agents, and thus they contribute to the decrease of uncertainty and frictions during transactions. North (1993) offers a similar definition of institutions: institutions are the rules of the game in a society or, more formally, are the human-devised constraints that shape human interaction.

Williamson (1998) suggested a hierarchy that proved very useful during our analysis. He separated social analysis into four levels (Figure 1). The different levels are ranked according to the time needed to change them, but they also show what influences what in the society. Higher levels directly influence the level just below them, meaning that no practices may be adopted on the lower levels that are not compatible with the superior levels. Social embeddedness is at the top of the hierarchy (L1). Williamson puts norms, customs, ethical principles, traditions, conventions and religion into this category. Some development factors found in the literature at least partly belong to this level (e.g. the dual structure of the society, entrepreneurial behaviour).

The institutional environment forms the second level (L2). While informal rules were placed in Level 1, the rules of L2 are formal, codified ones (e.g. constitution, laws, property rights). Although the change of Level 2 rules is also partly evolutionary in nature, calculated interference is also possible on this level (unlike on L1). Such interferences are called firstorder economising, which is about finding the ideal combination of formal rules. Many of the development factors belong to the institutional environment: the rule of law, democratic rights, market regulation and protectionism.

First-order economising, however, does not ensure the optimal economic structure. As agents behave opportunistically, they do not keep to the formal rules of the economy all the time. Jurisdiction also has its frictions, meaning that those who follow the rules are not always able to enforce their rights against opportunists instantly and without any costs. This is where the third level (L3) kicks in, called governance by Williamson. The unit of analysis in governance is the transactions made among economic agents, and the contracts mediating those transactions. Such development factors as the coordination of education 
and research, Porter's national diamond, government failures or rent seeking, can all be reckoned among L3 items.

The final level (L4) is concerned with the allocation of resources, an area which is traditionally addressed by neoclassical economics. The factors of the better-known growth theories (quantities of labour and capital, savings, investments, etc.) all belong to this level. Williams thinks that new institutional economics addresses problems belonging mainly to Levels 2 and 3. North's and Hodgson's definitions cited above, however, suggest that all phenomena belonging to L1, L2 and L3 can be regarded as institutions. This paper therefore treats all factors as institutional factors that can be categorised in one of the top three levels of Williamson's hierarchy.

\section{Figure 1: Economics of institutions}

Level

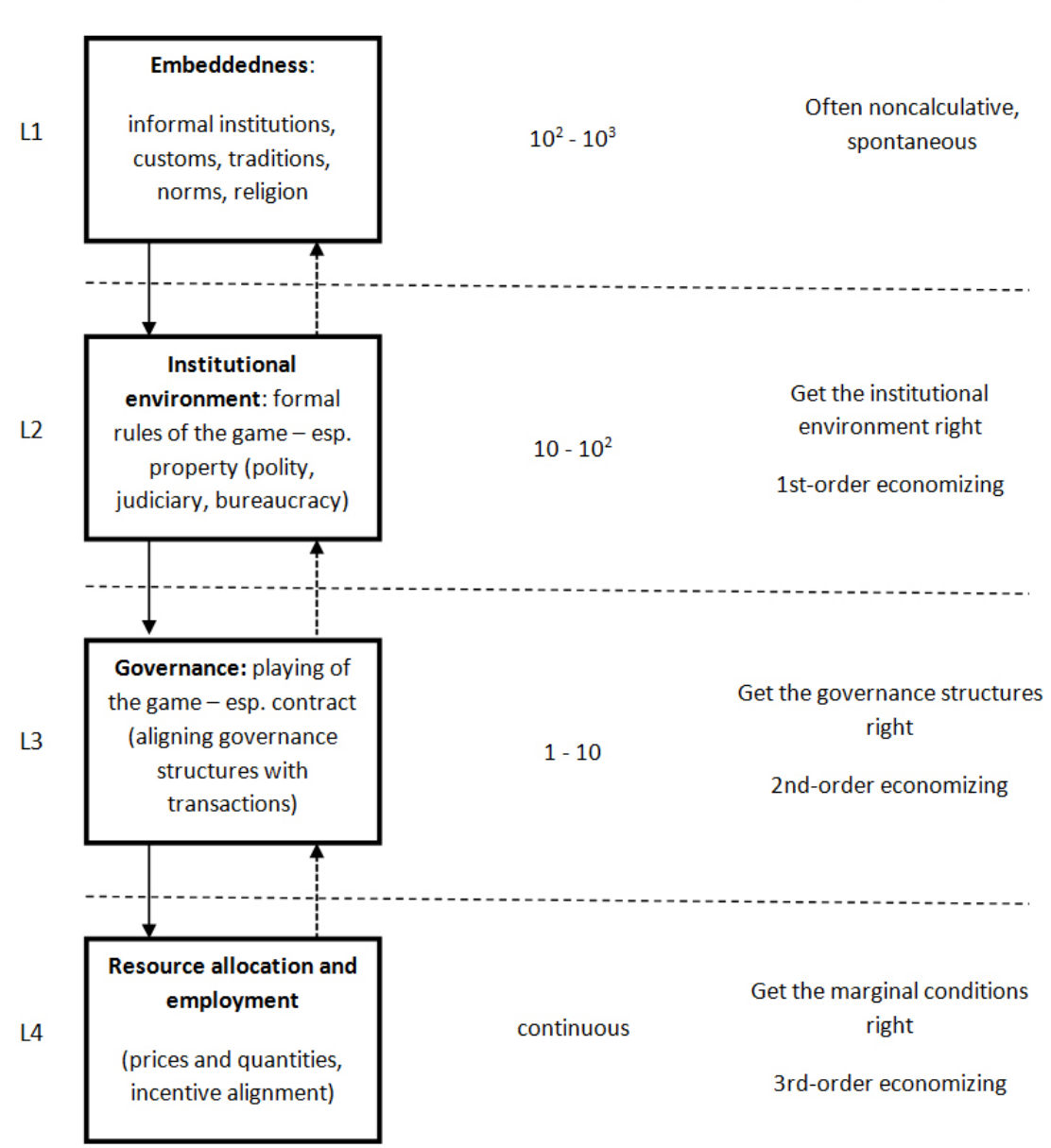

Source: Williamson, 1998, p. 26 


\section{Methodology \\ Structure of the model}

To identify the crucial development factors of Hungary, and in order to sketch potential development paths for the country, we developed the FOI model. The model is primarily based on the factors collected from the literature, but these factors are structured in a unique way which allows us to draw up characteristic development paths that can be clearly separated from each other. We used the following assumptions when the FOI model was set up:

- National economies are the unit of our analysis; international interdependencies are mostly disregarded in the paper.

- The key to development is not a single factor, but rather a combination of many factors. According to our assumption there are several important motors of development; sometimes these factors influence each other, and it is very difficult to determine what causes what; still, they can be equally important, and they all have to be used to draw up a potential development path for Hungary.

- Among the many factors considered in the model, the so-called institutional factors play a primary role. Institutional factors are detected using the hierarchy put forward by Williamson (1998). In fact, the model was developed with the aim of stressing the importance of institutional factors in development.

- Development can take more than one shape and form. There are several feasible development paths, and Hungary is not constrained to follow only one of them, but may choose from a (limited) number of such paths. To determine these development paths, the FOI model was used to test OECD countries.

The FOI model offers a new typology of development factors, but is also capable of structuring these factors along three clear directions of development. As shown previously, the inside-outside typology of development factors is a standard part of the literature. The FOI model, however, is based on a three-dimensional structure. These three dimensions are:

- F, i.e. the future potential of a country;

- O, i.e. the outside potential of a country;

- I, i.e. the inside potential of a country.

All three dimensions are complex and composed of a large number of factors. However, they can still be clearly distinguished from each other, which is useful because this clear distinction can help in the formulation of distinctive development strategies.

Future potential includes factors that are regarded as crucial for the sustainability and future competitiveness of the Hungarian economy. As sustainability has become one of the main paradigms of all social sciences, we felt that the inclusion of it as a separate development dimension was essential. In our case, sustainability translates to ensuring that the typical signs and indicators of a developed country characterise not only the current state of the economy but also the relatively distant future. 
Outside potential includes factors crucial to the current world market position of Hungary. This second dimension can be treated as equivalent to the outside factors listed based on the literature. Some elements of the outside potential may not be influenced from the inside; others, such as the conditions affecting the international flow of goods, services and factors of production, are a standard part of economic policy.

Inside potential is made up of factors that are regarded as crucial to the current well-being and development of Hungary. Most of the inside factors listed in Table 1 fall into the category of this potential. Countries which offer favourable conditions to local entrepreneurs, and provide a high level of quality of life to their inhabitants, can have remarkable inside potential.

It is not difficult to spot that certain trade-offs exist among the three potentials. Higher wage levels, for example, are absolutely favourable from the perspective of inside potential, but they can be dangerous for the outside potential of the country. They can also be threatening to future potential, if the result of a high wage level is overconsumption. If a country is well endowed with natural resources, this can boost its inside and outside potentials, but the abundance of resources usually leads to high proportions of waste, which again harms future potential. The three potentials were drafted with these trade-offs in mind.

\section{Formulating a measurement method}

During a brainstorming session a list of 50 indicators was compiled with the help of experts. These 50 indicators were chosen to measure the relevant development factors and were all included in a questionnaire. Experts were asked to rank all 50 indicators on a 1-7 scale $(1=$ not at all relevant; $7=$ of highest significance $)$. Each indicator received three separate scores: one for future potential, one for outside potential and one for inside potential. The respondents had to give a high score to an indicator if they believed it greatly contributed to the sustainability and future competitiveness (F potential), current world market position (O potential) or current well-being (I potential) of Hungary. The questionnaire was completed by 28 experts. Most were active members of the Committee on Future Research of the Hungarian Academy of Sciences. Representing several academic fields (arts, engineering, medicine, natural and social sciences), they offered a wide perspective and a strong future-oriented attitude, values that are highly useful in this kind of research.

During the processing of the questionnaires, every indicator was placed in the group (F, $\mathrm{O}$ or I potential) where it scored highest, meaning that an indicator could only be part of one of the potentials. In order to eliminate some of the less important factors (which received low scores in all three dimensions), we disregarded everything that had a score below average. The final transformation left us with 27 factors: 12 of them influence the future potential, 10 the inside and 5 the outside potential (Table 2). 
Table 2: The components of the future, outside and inside potentials

\begin{tabular}{|l|l|l|}
\hline \multicolumn{1}{|c|}{ Future potential } & \multicolumn{1}{c|}{ Outside potential } & \multicolumn{1}{c|}{ Inside potential } \\
\hline Social responsibility (L1-3) & Trade to GDP ratio (L3-4) & $\begin{array}{l}\text { Burden of government } \\
\text { regulation (L2-3) }\end{array}$ \\
\hline Industrial disputes (L1) & Country credit rating (L4) & Quality of life (L4) \\
\hline Energy infrastructure (L3) & Exchange rate stability (L3) & $\begin{array}{l}\text { Collected total tax revenues } \\
\text { (L3) }\end{array}$ \\
\hline $\begin{array}{l}\text { Total public expenditure on } \\
\text { education per capita (L3) }\end{array}$ & $\begin{array}{l}\text { Financial institutions' } \\
\text { transparency (L3) }\end{array}$ & Pension funding (L2-3) \\
\hline Ageing of society (L1-2) & English proficiency (L4) & GDP (PPP) per capita (L4) \\
\hline Renewable energies (L3) & Real GDP Growth (L4) & Healthy life expectancy (L3) \\
\hline Ease of access to loans (L3) & Ecological footprint (L1-2) & Rigidity of employment (L3) \\
\hline $\begin{array}{l}\text { Total expenditure on R\&D per } \\
\text { capita (L3) }\end{array}$ & & Labour force (L4) \\
\hline $\begin{array}{l}\text { Total R\&D personnel } \\
\text { nationwide per capita (L3) }\end{array}$ & & Skilled labour (L3) \\
\hline $\begin{array}{l}\text { Educational assessment / } \\
\text { Mathematics (L3) }\end{array}$ & & \\
\hline
\end{tabular}

The final version of the model was fine-tuned using statistical data from OECD countries.

\section{FOI analysis of OECD countries}

To quantify the future, outside and inside potentials, the FOI-indices were calculated. The value of the 27 components (listed in Table 2) were gathered for all 34 OECD members for the year 2010, and then all values were transformed to a 1-7 scale using the min-max method. By averaging the standardised values, we were able to calculate the F-, O- and I-indices of all 34 countries (Table 3 ).

Table 3: The F-, O- and I-indices of OECD countries

\begin{tabular}{|lccclccc|}
\hline & $\mathrm{F}$ & $\mathrm{O}$ & $\mathrm{I}$ & & $\mathrm{F}$ & $\mathrm{O}$ & $\mathrm{I}$ \\
\hline Australia & 4.20 & 5.32 & 4.35 & Japan & 4.80 & 3.68 & 4.01 \\
Austria & 4.70 & 5.41 & 4.05 & South Korea & 4.00 & 4.26 & 3.33 \\
Belgium & 3.90 & 5.56 & 3.47 & Luxembourg & 5.30 & 6.56 & 4.45 \\
Canada & 3.90 & 5.41 & 4.50 & Mexico & 2.70 & 3.98 & 2.85 \\
Chile & 3.80 & 5.03 & 4.13 & Netherlands & 4.40 & 5.54 & 3.83 \\
Czech Republic & 3.10 & 4.97 & 3.57 & New Zealand & 4.20 & 4.52 & 4.00 \\
Denmark & 4.80 & 5.77 & 4.30 & Norway & 5.20 & 5.70 & 4.13 \\
Estonia & 3.00 & 4.94 & 3.08 & Poland & 2.90 & 4.42 & 3.07 \\
Finland & 5.00 & 5.72 & 4.02 & Portugal & 3.50 & 4.33 & 2.91 \\
France & 4.40 & 4.46 & 3.04 & Slovakia & 3.00 & 4.82 & 3.25 \\
Germany & 4.30 & 5.26 & 3.73 & Slovenia & 3.40 & 5.08 & 2.70 \\
Greece & 2.90 & 3.66 & 2.50 & Spain & 3.40 & 4.23 & 2.99 \\
Hungary & 2.90 & 4.56 & 2.55 & Sweden & 5.10 & 5.22 & 4.13 \\
Iceland & 5.90 & 2.33 & 4.42 & Switzerland & 5.40 & 5.37 & 4.89 \\
Ireland & 3.90 & 4.17 & 3.91 & Turkey & 3.30 & 3.63 & 3.14 \\
Israel & 3.60 & 4.89 & 4.13 & United Kingdom & 3.90 & 4.35 & 3.60 \\
Italy & 3.50 & 3.82 & 2.66 & USA & 3.80 & 4.27 & 4.47 \\
\hline
\end{tabular}




\section{Factor analysis}

In order to better understand what background factors drive the value of the different F-, O- and I-indices, a factor analysis was conducted with SPSS 19. Almost 150 variables were tested during the analysis. In the first step, we checked how closely related those variables are to the three index values in OECD countries, and what the direction of the relationship is. As a second step, all variables were only considered in the factor analysis of the index they had the highest correlational relationship with.

We were able to establish three main groups of indicators that showed a significant correlation with the index of the future potential of OECD countries. They were labelled Human capital, Accountable corporations and Quality of the education system. The Human capital factor is a combination of indicators measuring the education and health sectors, and productivity. The Accountable corporations factor combines such factors as the ethical and social responsibility of organisations and the credibility of managers, and so represents the social, ethical and environmental considerations of businesses. The third factor, Quality of the education system, shows the returns on efforts made in the education system.

Two factors were found with the factor analysis of the O-index, namely National goodwill and Investment conditions. The main distinction between the two factors is the timeframe within which their indicators may be influenced by the decision maker. The Investment conditions factor includes variables that can be influenced relatively easily, even over the short term; the National goodwill, on the other hand, may only be changed over the very long term.

Variables having a significant correlation with the I-index can be separated into three factors. These factors were labelled Business competitiveness, Government intervention and Availability of resources. The Business competitiveness factor measures the microeconomic position of all businesses (small and medium-sized enterprises and large corporations) along such dimensions as productivity, efficiency and R\&D\&I. The other two factors describe the macroeconomic environment of the businesses, where the Government interventions consists of the regulation part and the Availability of resources the allocation part. 
Table 4: The factors of the F-, O- and I-index

\begin{tabular}{|c|c|c|}
\hline F-index & O-index & I-index \\
\hline F1 Human capital & O1 National goodwill & I1 Business competitiveness \\
\hline $\begin{array}{l}\text { Labour productivity (PPP) } \\
\text { Overall productivity (PPP) } \\
\text { Total health expenditure per } \\
\text { capita } \\
\text { Total public expenditure on } \\
\text { education per capita } \\
\text { Healthy life expectancy } \\
\text { Total expenditure on R\&D per } \\
\text { capita }\end{array}$ & $\begin{array}{l}\text { Parallel economy } \\
\text { Investment risk } \\
\text { Image abroad } \\
\text { Country } \\
\text { credit rating } \\
\text { Brain drain } \\
\text { Risk of political instability }\end{array}$ & $\begin{array}{l}\text { Innovative capacity } \\
\text { Productivity of companies } \\
\text { Small and medium-size } \\
\text { enterprises } \\
\text { Information technology } \\
\text { Large corporations }\end{array}$ \\
\hline F2 Accountable corporations & O2 Investment conditions & I2 Government intervention \\
\hline $\begin{array}{l}\text { Ethical practices } \\
\text { Social responsibility } \\
\text { Credibility of managers }\end{array}$ & $\begin{array}{l}\text { Foreign investors } \\
\text { Exchange rate stability } \\
\text { Capital markets } \\
\text { Investment incentives } \\
\text { State ownership of enterprises }\end{array}$ & $\begin{array}{l}\text { Subsidies } \\
\text { Finance and banking } \\
\text { regulation } \\
\text { Protectionism } \\
\text { Legal and regulatory } \\
\text { framework } \\
\text { Ease of doing business } \\
\text { Bureaucracy }\end{array}$ \\
\hline $\begin{array}{l}\text { F3 Quality of the education } \\
\text { system }\end{array}$ & & I3 Availability of resources \\
\hline $\begin{array}{l}\text { Educational assessment / } \\
\text { Mathematics } \\
\text { Educational assessment / } \\
\text { Sciences } \\
\text { Science in schools } \\
\text { Educational system }\end{array}$ & & $\begin{array}{l}\text { Labour force } \\
\text { Total primary energy supply } \\
\text { per capita } \\
\text { Burden of government } \\
\text { regulation } \\
\text { Employment rate } \\
\text { Gross domestic savings }\end{array}$ \\
\hline
\end{tabular}

F-index: $K M O=0.823$, explained proportion 76.4\%; $O$-index: $K M O=0.803$, explained proportion $73.7 \%$; I-index: $K M O=0.791$, explained proportion $73.408 \%{ }^{3}$

\section{Forming clusters}

The FOI-indices and the factors determined during the factor analysis were used to identify typical clusters within OECD countries. These artificial clusters were created based on the values of the F-, O- , and I-index, with the so-called half-scale method. As the indices can have a value between 1 and 7, 4 is the mid-value. So all three indices were split into two groups: the values from 1 to 4 went into the group labelled as "low" (1), while the values above 4 were labelled as "high" (2).

Theoretically, all 8 clusters could represent feasible combinations, but most of the 34 OECD members fall into 4 groups (the distribution is shown in Table 5). In our interpretation these

${ }^{3}$ The Kaiser-Meyer-Olkin (KMO) value helps in determining how suited our variables are to factor analysis. A KMO value above 0.8 means that the variables are highly suitable. Principal component analysis and Varimax rotation were used during the analysis. 
four groups of countries represent the development models within the OECD. The current paper focuses on group nr. 7, which is called the large corporation-based, bureaucratic model. As half-scaling was used as a method of clustering, it is obvious that Belgium, France, Netherlands, Ireland, South Korea and New Zealand perform above average in their future and outside potential.

A closer inspection of the factors shows however, that these countries are especially strong on the field of Accountable corporations, while their Human capital endowments and the Quality of the education system (the other factors of the F-index) are barely above average. The factors of the O-index show a balanced performance. Group nr. 7 is below average in the I-index, but a more sophisticated picture can again be drawn based on the factors: Business competitiveness is above average, but the factors describing the macroeconomic environment (Government intervention and Availability of resources) indicate below average performance.

Table 5: The clusters of OECD countries according to the half-scale method

\begin{tabular}{|ll|}
\hline Code & Country \\
\hline $1(111)$ & Greece, Italy, Mexico, Portugal, Turkey \\
$3(112)$ & Chile, Czech Republic, Estonia, Hungary, Israel, Poland, Slovakia, Slovenia, Spain \\
$5(211)$ & United Kingdom \\
$6(212)$ & Iceland \\
$7(221)$ & Belgium, France, Netherlands, Ireland, South Korea, New Zealand \\
$8(222)$ & Australia, Austria, Canada, Denmark, Finland, Germany, Japan, Luxemburg, Norway, \\
& Sweden, Switzerland, United States \\
\hline
\end{tabular}

The $F$-, $O$ - and I-index values indicated in brackets, where $1=$ countries with index values between 1 and 4;2 = above 4. No countries fell into group 2 and 4.

Group 7 is called the large corporation-based, bureaucratic model for two reasons. On the one hand, these countries perform really well in two factors measuring the performance of the business sector (they excel in Accountable corporations and are above the average in Business competitiveness). On the other hand, they fall below average in the regulatory environment and in the availability of local resources (both indicate the presence of extensive state regulation that often overwrites market decisions).

\section{The large corporation-based, bureaucratic model as a development strategy}

The cluster and factor analysis based on the FOI-indices led us to three promising development models (cluster 3, 7 and 8). The paper discusses the large corporation-based, bureaucratic model in detail, which implies a defensive strategy that is focused on the creation of local safe havens. In other words we argue that, if the goal is to move towards the large corporation-based, bureaucratic model, then economic policy should primarily be defensive and protectionist, concentrating on creating an environment for large domestic corporations that at least partially protects them from global competition.

By drawing a parallel between the development model (deducted from the clusters of countries) and economic policy strategy, we can also tell which factors are most important 
for the local safe haven-oriented defensive strategy. Based on our analysis, we can tell those factors in which the countries belonging to different clusters (which represent possible development models within the OECD) perform exceptionally well. These outstanding factors then can be rendered to the development strategies. For the countries belonging to Cluster 7, the outstanding factors are the following: F2 Accountable corporations; I1 Business competitiveness; I3 Availability of resources (the latter factor also has a significantly high value for cluster 8).

As a next step, we checked which of the OECD members scored well in these three factors, and which of them has a comparable size to Hungary. Finland is number one in F2 Accountable corporations among OECD countries. Denmark is second, Austria is third in I1 Business competitiveness, while Norway is fifth in I3 Availability of resources. Country studies were prepared of the four countries (Austria, Denmark, Finland and Norway) to detect those best practices that allowed them to excel in the areas measured by the key factors listed above. The country studies are fairly extensive and therefore cannot be included in the paper, but the lessons learned from them are featured in the final sections (the country studies are accessible in the Appendix of Bartha, Gubik and Tóthne Szita, 2013). The final goal is to use the FOI analysis and the country studies to offer relevant policy recommendations for Hungary.

\section{A defensive strategy focused on the creation of local safe havens}

As part of a strategy focused on the creation of local safe havens, the state is committed to creating and sustaining a regulatory safety net that enables a well-functioning corporateenterprise sector (with the emphasis being on large national corporations). According to our model, the strategy is best described by the accountable (F2) and competitive (I1) business sector. The availability of resources (I3) is also key, however this factor is also featured in another strategy represented by Cluster 8 .

Table 6: Development areas for a strategy focused on the creation of local safe havens

\begin{tabular}{|l|l|}
\hline Level & Component \\
\hline L1 & $\begin{array}{l}\text { Value system characterised by low level of power distance } \\
\text { Feminine culture } \\
\text { Long-term orientation in resource management* }\end{array}$ \\
\hline L2 & Social acceptance of entrepreneurs* \\
\hline L2-L3 transition & $\begin{array}{l}\text { Supportive role of the state } \\
\text { Favourable business environment* }\end{array}$ \\
\hline L3 & $\begin{array}{l}\text { Education system supporting the needs of the business sector } \\
\text { Ease of starting new businesses, assistance provided for new entrepreneurs }\end{array}$ \\
\hline L4 & $\begin{array}{l}\text { R\&D\&I incentives } \\
\text { Supporting cluster development } \\
\text { Avoiding price competition by making use of special market niches } \\
\text { Extensive ITC use } \\
\text { Geographical position, exploiting domestic endowments } \\
\text { Qualified and productive labour force* }\end{array}$ \\
\hline
\end{tabular}

*Key components of cluster 8 as well. 
Hungary performs rather poorly in the key factors of the strategy focused on the creation of local safe havens. It is ranked $20^{\text {th }}$ in Accountable corporations (F2), $26^{\text {th }}$ in Business competitiveness (I1), and $33^{\text {rd }}$ (last but one within the OECD) in Availability of resources (I3). There is plenty to be done if the local safe haven strategy is chosen. Table 6 contains those key components that were collected from the country studies (analysing the best practices of countries doing exceptionally well in factors F2, I1 and I3). They can set the development priorities for a local safe haven-oriented economic policy strategy. The components are presented in the hierarchical order suggested by Williamson (see Figure 1). According to our country studies, the low level of power distance and the feminine nature of the culture are the most deep-rooted elements of this strategy. Both contribute to the accountability of firms. The low power distance, because the horizontal employee-employer, company-stakeholder, company-supplier relations make it possible for less powerful parties to have a say in the principles according to which the companies are managed. The feminine culture, because it represents a high level of social solidarity, an element that is crucial to the social responsibility of companies.

These two components, however, are ranked at the highest level of Williamson's hierarchy (L1), which means that the chance of influencing them is minimal. However, they still have to be mentioned, as the nature of the hierarchy is that the components high up have an effect on the lower levels (which are easier to manipulate). A decision has to be made whether or not it is possible to balance the lack of L1 components with lower level changes, and whether or not the strategy can be successful without having the proper L1 cultural elements in place, before any steps are taken to move the economy toward the large corporation-based, bureaucratic model. For example, the lack of trust which can be a consequence of a masculine culture (L1), might be replaced by such formal governance structures (L3) as can minimize transaction costs.

The long-term orientation towards resource management is also on the top level of the hierarchy. The responsible and sustainable use of natural resources is partially dependent on the institutional structures (L2, the vision driving long-term government decisions), but long-term orientation is a characteristic of the society as a whole (see Cernic, 2012, for an example on the importance of long-term orientation). Norway offers prime examples of this, be it the management of oil extraction, or the preservation policy followed regarding the renewable resources possessed by the country. But Norway's efforts in sustainability go way beyond the national borders. Prime Minister Gro Harlem Brundtland offered a great example of the international role played by Norway in matters of sustainability when she participated in the drafting of the report titled Our Common Future. The main message of the report, a "development that meets the needs of the present without compromising the ability of future generations to meet their own needs" (WCED 1987, p. 27), has become the most often quoted definition of sustainable development.

A critical element of the institutional structure (L2) for the strategy focused on the creation of local safe havens, is the social acceptance of entrepreneurs and entrepreneurial behaviour in general. This component can be influenced, and, through education and proper communication, the attitude towards entrepreneurship can be changed within a reasonable amount of time (although this still means several years, possibly decades). 
The supportive role of the state is also key to this strategy. This factor is only part of the institutional structure, so it was put as a transition element between Levels 2 and 3. In Finland, for example, the country that is first in Accountable corporations, government support was crucial in establishing world-leading social responsibility practices. It is also worth mentioning that the state's role is more that of night-watchman, focused on coordination and harmonization, rather than direct control (according to the WTI, the tax burden of Cluster 7 countries is not significantly high within the OECD, MachovaKotlan, 2013). The favourable business environment is also part of the L2-L3 transition level, which is driven by the good availability of resources, on the one hand, and by the regulation of the state, on the other.

On the level of governance (L3), the following are the key ideas: what are the administrative costs of starting and operating a private business; and what is the state's contribution to the competitiveness of domestic companies. The technical and administrative costs of starting a new business in Denmark are minimal. Furthermore, new entrepreneurs receive consultancy services partially funded by the central budget. Norway, where starting a new business is also cheap and quick in international comparison, excels in the availability of financial resources (availability of credit and risk capital).

The structure and the efficiency of the education system is also crucial to the competitiveness of the business sector. The country studies of both Austria and Denmark shed light on the importance of ITC use and foreign language skills alongside a high level of professional skills. The traditional educational system and lifelong learning structures both contribute to good performance in these fields. Denmark's example also shows how the involvement of stakeholders contributes to higher quality in education. Parents and students, through school councils, and companies, through apprenticeship programs, have a say in key education matters (such as curricula, student schedules, apprenticeship).

Level 4 (L4) covers those components related to the allocation of resources in general, and especially to labour market issues. A change on this level can have immediate effects. One of the key elements on L4 is cluster development. Clusters play an important role in the economy both in Austria and in Denmark. Industry-level cooperation has great traditions in both countries, so the development of clusters is a result of a natural process. Formal automotive industry cooperation has a 100-year history in Austria, and the Danish agribusiness, wind power and pharmaceutical industry clusters are also good examples of such development.

Competitiveness is sustained through the setting of proper development priorities, and government incentives for R\&D\&I. R\&D spending in Austria has grown the fastest within the European Union. Private funding of $R \& D$ is on the rise as well, a process that is driven by tax benefits and direct transfers. As a result of public support, cooperation between private firms and universities and research institutes is getting stronger. Although it has to be mentioned again, that cooperation is also strengthened by cultural elements. The low power distance (Hofstede, 2001) and the horizontal nature of relationships (in which Austria ranks first, Denmark third) both help a lot.

Austria and Denmark can rely on their developed physical infrastructure, and can exploit their geographical position and unique endowments. Stressing the importance of 
uniqueness is also part of their market strategy. Many Austrian firms, for example, try to make use of special market niches, and so can avoid global price competition. They operate in traditional industries, where special knowledge is needed, and high market share can be achieved because of the high quality of the products.

Last but not least, the highly qualified and efficient labour force is also a key L4 component (although this is also a significant factor of Cluster 8). Some lessons to be learned from the Norwegian country study include: the identifying and prioritising of fields of education (mathematics, natural sciences and entrepreneurial studies in the case of Norway); high involvement in lifelong learning; high proportion of GDP spent on education.

\section{Conclusion}

The large corporation-based, bureaucratic model requires a defensive strategy focused on the creation of local safe havens. This model can also be interpreted as a modern version of protectionism. It can be characterised by a well-functioning large corporation sector, but this is partially due to the high level involvement of the state. This is important in the global environment, because the state can create a sort of safe haven for domestic companies. It is unclear, however, just how long this safe haven can be sustained in a global environment where state regulation is becoming more and more uniformalised.

According to our country studies, by supporting cooperation between firms, among firms, universities and research institutes, cooperation within clusters, the economic policy of a country can move toward a strategy focused on the creation of local safe havens. Intensive public support is required to sustain the competitiveness of the corporate sector, which is partially achieved by creating and sustaining a reliable incentives environment (e.g. intellectual property rights, start-up regulation, flexible labour market, financial resources), and partially by taking an active role (e.g. education, $R \& D$ funding, infrastructure).

The role of the state can also be extended on the identification and exploiting of unique endowments (e.g. special national goods, market niches). This can be done through consultancy services, or through providing publicly funded added value (e.g. marketing), or even through providing public support to encourage entrepreneurial involvement.

The other cornerstone of the strategy is an education system that provides such competitive skills and knowledge that suit the needs of large corporations, but also help people if they want to become self-employed. An education system like that can set the supply to the needs of the labour market, can involve the stakeholders of the system (parents, students and companies), and can offer a reliable alternative for teachers.

\section{Acknowledgements}

The paper was prepared within the framework of OTKA project nr. K 76870/2009-2013. 


\section{References}

Balogh, T. (1963). Unequal Partners, 1-2. Oxford: Blackwell.

Barro, J. B. (1998). Determinants of Economic Growth: A Cross-Country Empirical Study. Cambridge: MIT Press Books.

Bartha, Z., Gubik, S. A., Tóthné Szita, K. (2013). Intézményi megoldások, fejlôdési modellek (Institutional solutions, development models). Miskolc: GNR Szolgáltató és Kereskedelmi Bt.

Bhagwati, J. (1958). Immiserizing Growth: A Geometrical Note. The Review of Economic Studies, 25(3), 201-205.

Boeke, J. H. (1953). Economics and Economic Policy of Dual Societies. New York: Institute of Pacific Relations.

Cernic, J. L. (2012). Corporate Obligations under the Right to a Healthy Living Environment. DANUBE: Law and Economics Review, 3(3), 21-41.

Coase, R. H. (1937). The Nature of the Firm. Economica, 4(16), 386-405.

Domar, E. (1947). Expansion and Employment. American Economic Review, 37(1), 343-355.

Emmanuel, A. (1972). Unequal Exchange: A Study of the Imperialism of Trade. New York: Monthly Review Press.

Freeman, C. (1987). Technology Policy and Economic Performance: Lessons from Japan. London: Pinter Publishers.

Furtado, C. (1970). Economic Development of Latin America. London: Cambridge University Press.

Hamilton, A. (1791). Report on Manufactures. Philadelphia.

Harrod, R. F. (1948). Towards a Dynamic Economics. London: MacMillan.

Hodgson, M. H. (2006). What Are Institutions? Journal of Economic Issues, 40(1), 1-25. Hofstede, G. (2001). Culture's Consequences: Comparing Values, Behaviors, Institutions and Organizations Across Nations. London: SAGE Publications.

Keynes, J. M. (1936). The General Theory of Employment, Interest and Money. London: MacMillan.

Krueger, A. O. (1974). The political economy of the rent seeking society. American Economic Review, 64(3), 291-303.

List, F. (1841). Das Nationale System der Politischen Ökonomie. Stuttgart: Cotta'schen Verlag.

Lucas, R. E. (1988). On the Mechanics of Economic Development. Journal of Monetary Economics, 22(1), 3-42.

Machova, Z., Kotlan, I. (2013). World Tax Index: New Methodology for OECD Countries, 2000-2010. DANUBE: Law and Economics Review, 4(2), 165-179.

McClelland, D. C. (1957). Community development and the nature of human motivation. Cambridge: Harvard University.

Meier, G. M. (1964). Leading Issues in Economic Development. New York: Oxford University Press.

Myrdal, G. (1957). Economic Theory and Underdeveloped Regions. London: Gerald Duckworth. 
North, D. C. (1993). Institutions, institutional change and economic performance. Cambridge: Cambridge University Press.

Porter, M. E. (1990). The Competitive Advantage of Nations. Harvard Business Review, 68(2), 73-91.

Prebisch, R. (1964). Towards a new trade policy for development. United Nations, New York.

Ricardo, D. (1817). On the Principles of Political Economy and Taxation. John Murray, London.

Romer, P. (1986). Increasing Return and Long Run Growth. Journal of Political Economy, 94(5), 1002-1037.

Schumpeter, J. A. (1934). The Theory of Economic Development: An Inquiry Into Profits, Capital, Credit, Interest, and the Business Cycle. Harvard University Press, Cambridge.

Simon, H. A. (1957). Models of Man. Wiley, New York.

Singer, H.W. (1964). International Development: Growth and Change. McGraw-Hill, New York.

Smith, A. (1776). Enquiry into the Nature and Causes of the Wealth of Nations. Edinburgh: J. R. McCulloch.

Solow, R. (1956). A Contribution to the Theory of Economic Growth. Quarterly Journal of Economics, 70(1), 65-94.

Szentes T. (2011). Fejlódés-gazdaságtan (Development economics). Budapest: Akadémiai Kiadó.

Tullock, G. (1967). The Welfare Costs of Tariffs, Monopolies and Theft. Western Economic Journal, 5(3), 224-232.

Tullock, G. (1993). Rent Seeking. Brookfield: Edward Elgar Publishing.

Veblen, T. (1919). The Place of Science in Modern Civilization. New York: B. W. Huensch. Wallerstein, I. (1974). The Modern World System: Capitalist Agriculture and the Origins of the European World Economy in the Sixteenth Century. New York: Academic Press. Williamson, O. E. (1998). Transaction Cost Economics: How It Works; Where It Is Headed. De Economist, 146(1), 23-58.

Williamson, O.E. (2000). The New Institutional Economics: Taking Stock, Looking Ahead. Journal of Economic Literature, 38(3), 595-613.

World Commission on Environment and Development (1987). Our Common Future. Oxford: Oxford University Press. 